\title{
HETEROCHROMATIC AND EUCHROMATIC GENES ACTING ON QUANTITATIVE CHARACTERS, IN D. MELANOGASTER
}

\author{
C. BARIGOZZI and A. DI PASQUALE \\ Istituto di Genetica, Universitò di Milano
}

Received 17. iii. 53

\section{INTRODUCTION}

THE last paper by the senior author (I95I) on the action exerted by the $\mathrm{Y}$ chromosome pointed out that, comparing stocks differing merely by the $\mathrm{Y}$ chromosome (known to be heterochromatic), size differences can be observed in the wing cells and in the eye corneæ. The Y chromosome's effect was then proved by comparing the differences between sexes; no comparison was made between males of different homogeneous stocks, i.e. by testing whether the different Y's produce an heterogeneity between males of different stocks. Nevertheless the conclusion seemed obvious, that the $\mathrm{Y}$ chromosome of D. melanogaster, except in a few loci, acts quantitatively on small characters ; this agrees fundamentally with the point of view expressed by Mather (1944, 1949). Further, the difference between the wild Y's was interpreted as being produced by different systems of genes interacting together.

The aim of the present work is now :-

(i) To complete the demonstration of the $\mathrm{Y}$ chromosome's action, using a new method which will be given below.

(ii) To secure further evidence in favour of the polygenic nature of the factors located in the $\mathrm{Y}$.

(iii) To compare the action of the $\mathrm{Y}$ chromosome with that of major genes located in euchromatin, in order to see whether discrimination is possible between heterochromatic and euchromatic genes.

\section{MATERIAL AND METHODS}

The material used in this investigation * is composed of the same group of stocks investigated previously (1951), namely: Crkwenika-Luino-Oerlikon-Oregon.

All the stocks had been made homogeneous for all chromosomes, except the $Y$ and the IVth pair.

It seemed important to us to compare the measurements of the characters made at two different times, i.e. some years ago and after an interval of nearly 20-30 generations; and to repeat afterwards the homogeneisation. This procedure was likely to indicate whether different mechanisms (mutation, recombination, selection, drift) can, as a whole, change a polygenic genotype.

* We are indebted to Miss E. Bassi for her valuable help in making preparations and counting, and to Mr H. Rees for revision in the English.

389 
With this aim, both characters already investigated (frequency of wing hairs, area of the cornex) were measured, $(a)$ before the homogenisation, $(b)$ immediately after the homogeneisation.

The homogenisation itself was carried out using the balanced stock: $\frac{C l B}{+}$ $\frac{\mathrm{P} m}{\mathrm{C} y \mathrm{~L}} \frac{\mathrm{H}}{\mathrm{S} b \mathrm{Me}}$, and Oregon as background, obtaining the following genotypes :

\begin{tabular}{|c|c|c|c|c|c|}
\hline & Males & & \multicolumn{3}{|c|}{ Females } \\
\hline $\mathrm{X}^{\text {Oregon }}$ & II ChrOregon & III ChrOregon & & & \\
\hline$\overline{\text { YOregon }}$ & $\overline{\text { II ChrOregon }}$ & $\overline{\text { III Chr Oregon }}$ & & & \\
\hline XOregon & ", & ," & always & & \\
\hline$\overline{\mathrm{Y} \text { Crkwenika }}$ & & & $\mathrm{X}^{\text {Oregon }}$ & IIOregon & IIIOregen \\
\hline$\frac{X^{\text {Oregon }}}{\text { YOerilikon }}$ & " & ", & $\overline{\mathrm{X}^{\text {Oregon }}}$ & $\overline{\text { IIOregon }}$ & $\overline{\text { IIIOregon }}$ \\
\hline$\frac{\text { XOregon }}{\overline{\text { YLuino }}}$ & $"$ & $"$ & & & \\
\hline
\end{tabular}

In the present investigation in order to obtain a comparable scaling for both wing cells and corneal areas, the reciprocal of the number of hairs counted in a given surface near cross vein II of the wing was used. Taking the area equal to I, the quantity $\frac{l}{n}$, where $n$ is the number of hairs, corresponds to the mean area, containing one hair, i.e. it is proportional to the mean area of the cells included in the standard surface.

The investigated characters are thus : the mean surface area of the wing cells and the mean surface area of the cornex of the compound eye ; each cornea comprises a fixed number ( 2 od 4 ) cells (see Barigozzi, 1951).

The comparisons between samples were always made by means of $F$ (variance ratio) to test the homogeneity or the heterogeneity of a group of flies supposed to have identical or different genotypes.

\section{OBSERVATIONS}

(a) Variations of intensity in wing hairs during four years (1948-1952) have been scored (see table I). The differences between sexes are

TABLE I

Differences between sexes and their errors

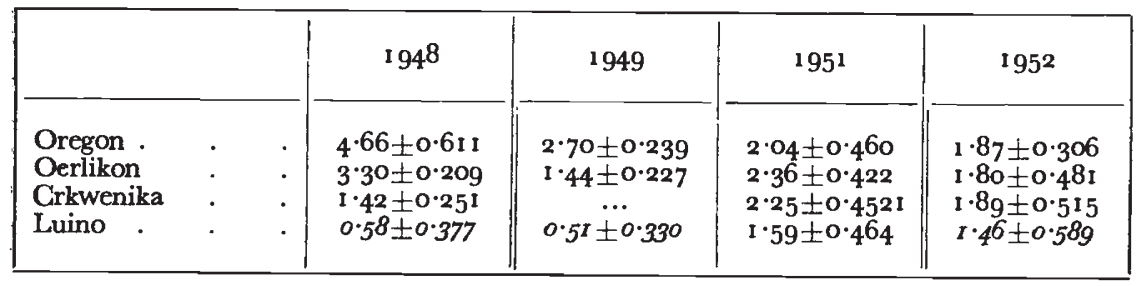

N.B.-The differences in italics are not significant.

given, and also the standard errors, so as to make the data comparable for samples that are not all of exactly the same magnitude.

It is worth noting that between 1948 and I 949 , and again between 1951 and I952 a substitution of genomes (oregonisation) took place, 
marked in the table with double vertical lines. One recognises that a change occurs in each interval, which covers about to generations per year.

The change is not very big, but is sufficient to show :-

(i) that many genes (polygenes) must act on the character, that are capable of causing a continuous genotypical change; the actual data appear discontinuous only because the observations also are discontinuous.

(ii) that the oregonisation, as a substitution of the entire genome, exerts an effect similar to the other mechanisms usually at work (mutation, recombination, etc.)

It is especially worth remarking on the data concerning Luino. The difference between sexes was not significant before and after the first oregonisation (1948-49), then became significant before the second oregonisation (195I), to become again insignificant afterwards.

From these facts it can be concluded that the character is influenced by different parts of the genome, and not only by the Y chromosome. A typical feature of the oregonisation (although not shown in the table) is that the change is suddenly produced. It is also worth noting that the oregonisation brings about an increase in the cell size in both sexes.

Furthermore it is important that the corresponding data on corneæ show similar trends to those on wing hairs.

(b) Homogeneity and heterogeneity of the oregonised stocks.-The working hypothesis used in this part of the investigation is the following: after a genome substitution, involving all chromosomes except the $\mathrm{Y}$ and the small IVth pair, the females must be practically alike in the different stocks, except for the IVth chromosomes, which might introduce a slight variation. The males, on the contrary, carrying a $\mathrm{Y}$ which is typical for each stock, may show differences between stocks.

To test this hypothesis, a comparison is necessary among males and females separately. It is also necessary to find out whether each stock is sufficiently homogeneous. From each stock, Io cultures were made (kept at a temperature of $25^{\circ}$ ) and from each culture 20 individuals (10 males and Io females) were investigated for the wing hairs; and 4 individuals ( 2 males and 2 females) for the cornex. The measurements were subjected to an analysis of variance, to test whether a sufficient degree of homogeneity within the stocks was reached.

Testing the variance between cultures against the variance within cultures by means of the $F$ variance ratio (with 9 and 90 degrees of freedom for the wing cells and with 9 and Io d.f. for the cornex), gave low values for $F$. This shows that variations within each stock can be considered with high probability as not significant (see table 2). Note that the $\mathrm{F}$ value of the cornex of the Luino females $(3.5476)$ 
reaches the level of significance at 5 per cent. $(3.02)$, and that of Luino males for the wing cells $(3 \cdot 1866)$ is also significant.

This conclusion that the stocks are in general homogeneous, permits us to take the mean of each culture instead of the individual measurements, in order to compare the variance between stocks with the variance within stocks, which is the second step of our investigation. With regard to the significant difference between the Luino males for wing cell size, the fact that the oregonisation procedure was the same for all stocks indicates that this heterogeneity must depend on a heterogeneity of the response to environment of

TABLE 2

Variance ratios within Oregonised stocks $\frac{\text { Variance between cultures }}{\text { Variance within cultures }}$

\begin{tabular}{|c|c|c|c|c|c|}
\hline & \multicolumn{2}{|c|}{$\begin{array}{l}\text { Wings }(N=100) \\
\text { D.F.: } 9 ; 90\end{array}$} & \multicolumn{2}{|c|}{$\begin{array}{c}\text { Cornex }(\mathrm{N}=20) \\
\text { D.F.: } 9 ; 10\end{array}$} \\
\hline & & o & $q$ & $\sigma$ & $q$ \\
\hline $\begin{array}{l}\text { Oregon } \\
\text { Crkwenika } \\
\text { Oerlikon } \\
\text { Luino . }\end{array}$ & $\begin{array}{l}\cdot \\
\cdot \\
\dot{5} \\
\dot{5}\end{array}$ & $\begin{array}{l}0.5222 \\
1 \cdot 6112 \\
0.9871 \\
3 \cdot 1866\end{array}$ & $\begin{array}{l}0 \cdot 6695 \\
0 \cdot 7413 \\
1 \cdot 3447 \\
0 \cdot 7484\end{array}$ & $\begin{array}{l}1 \cdot 5857 \\
I \cdot 001 \\
0 \cdot 5506 \\
I \cdot 2756\end{array}$ & $\begin{array}{l}0.4639 \\
2.6329 \\
1.6516 \\
3.5476\end{array}$ \\
\hline
\end{tabular}

$\mathrm{P}$ always $>5$ per cent., except : males Luino for wing cells, where $\mathrm{P}<\mathrm{r}$ per cent.

the Luino males. This fact does not allow us to attribute to this mean the same significance as to the others, but does not affect the discrimination between stocks.

When the variance between stocks is tested against the variance within cultures of each stock, separately for females and males, the following results are obtained (table 3 ). The variation of areas for the wing cells does not show any significant heterogeneity for the females, while a highly significant heterogeneity is observed for the males. This means that, in agreement with expectation, the female genotype is fundamentally the same in all stocks, while this is not the case for the males. Since between stocks the main source of difference is the $\mathrm{Y}$ chromosome, it seems reasonable to interpret the discrepancies among the males for different stocks, as being due mainly to $\mathrm{Y}$ chromosome effects.

It is also worth noting that this effect is similar for both the characters studied. In addition, the fact that the wing cells show a high variability within the Luino males is a further evidence for different activities of the different $Y$ 's. The $Y$ of Luino thus seems to be characterised by a weaker genotypic control of the character under consideration. The demonstration of the influence of the $\mathrm{Y}$ chromosome on cell size is in accordance with the previous observation made by one of us (Barigozzi, I95I).

If it seems justified to ascribe to the $\mathrm{Y}$ chromosome a prevalent 
action in determining the high variation in cell size of the males, it does not follow that this variation depends solely on that. We cannot disregard the fact that in the procedure of homogeneisation

TABLE 3

\begin{tabular}{|c|c|c|c|c|c|c|c|c|}
\hline & \multicolumn{4}{|c|}{ Wing cells-Females } & \multicolumn{4}{|c|}{ Corneæ-Females } \\
\hline & Crkwenika & Oerlikon & Oregon & Luino & Crkwenika & Oerlikon & Oregon & Luino \\
\hline I & 0.08920 & 0.0884 & 0.0909 & 0.0925 & $3 I 8 \cdot 29 I$ & $344^{\circ}$ I 2 I & 3 OI $\cdot$ I 39 & $306 \cdot 934$ \\
\hline 2 & 0.09009 & $0 \cdot 0909$ & 0.0943 & 0.0934 & 319.303 & $34^{6} \cdot 03^{6}$ & $33^{6 \cdot 611}$ & 307.533 \\
\hline 3 & o.ogoog & 0.0917 & 0.0943 & 0.0934 & $3^{24} \cdot 987$ & $355 \cdot 93^{2}$ & $340 \cdot 068$ & 3 I $3 \cdot 73^{8}$ \\
\hline 4 & $0 \cdot 09170$ & 0.0934 & 0.0943 & 0.0943 & $328 \cdot I 63$ & $3^{6} 3 \cdot 77^{6}$ & $353 \cdot 310$ & $3^{16} \cdot 73^{2}$ \\
\hline 5 & $0.0925^{\circ}$ & 0.0943 & $0.095^{2}$ & 0.0965 & $339 \cdot 773$ & 378.022 & $353 \cdot 3^{6} 9$ & $317 \cdot 635$ \\
\hline 6 & 0.09250 & 0.0952 & 0.0952 & 0.0970 & $346 \cdot 909$ & 384 . I I 7 & $354 \cdot 254$ & $328 \cdot 904$ \\
\hline 7 & 0.09340 & $0.095^{2}$ & 0.0961 & 0.0978 & $350 \cdot 070$ & $3^{86 \cdot 017}$ & $359 \cdot 368$ & $33^{8 \cdot 1} 62$ \\
\hline 8 & 0.09340 & $0.095^{2}$ & $0.096 \mathrm{I}$ & 0.0980 & $35 \mathrm{I} \cdot \mathrm{I} 4 \mathrm{I}$ & $3^{8} 7 \cdot 73^{2}$ & $371 \cdot 306$ & $339 \cdot 340$ \\
\hline 9 & 0.09520 & $0 \cdot 0961$ & 0.0970 & 0.0980 & $3^{6} 5^{\circ} \cdot 024$ & 4I 5.675 & 37 I 826 & $354 \cdot 223$ \\
\hline IO & 0.09800 & 0.1000 & 0.0980 & O.IOIO & $37^{2} \cdot 240$ & $42 \mathrm{I} \cdot 083$ & $372 \cdot 298$ & $3^{60} \cdot 124$ \\
\hline Means & $0 \cdot 092608$ & 0.09404 & 0.09514 & 0.096 I 9 & $341 \cdot 590$ & $37^{8} \cdot 25^{I}$ & $35^{I} \cdot 354$ & $328 \cdot 33^{2}$ \\
\hline
\end{tabular}

D.F. : $3 ; 3^{6 .} \quad \mathrm{F}=\mathrm{I} \cdot 73^{8}$. P> 5 per cent.
D.F. : $3 ; 36 . \quad F=2 \cdot 328$.

$\mathrm{P}>5$ per cent.

\begin{tabular}{|c|c|c|c|c|c|c|c|c|}
\hline & \multicolumn{4}{|c|}{ Males } & \multicolumn{4}{|c|}{ Males } \\
\hline I & 0.0746 & 0.0763 & $0.078 \mathrm{I}$ & 0.0793 & $262 \cdot 146$ & $307 \cdot 286$ & $306 \cdot 001$ & $262 \cdot 96_{I}$ \\
\hline 2 & $0.07^{6} 9$ & 0.0775 & 0.0793 & 0.0800 & $289 \cdot 5^{6}$ & $308 \cdot 386$ & $308 \cdot 692$ & $27 \mathrm{I} \cdot 080$ \\
\hline 3 & 0.0775 & $0.078 \mathrm{I}$ & 0.0800 & 0.0800 & $296 \cdot 733$ & $325 \cdot 380$ & $309.66_{3}$ & $293 \cdot 092$ \\
\hline 4 & 0.0775 & $0 \cdot 0800$ & 0.0800 & 0.0819 & $297 \cdot 224$ & $326 \cdot 2$ I 4 & 310.655 & $293 \cdot 268$ \\
\hline 5 & 0.0787 & 0.0806 & 0.0800 & 0.0854 & $302 \cdot 182$ & $3^{28} \cdot 727$ & 317.016 & $29^{8} \cdot 3^{24}$ \\
\hline 6 & 0.0787 & $0.08 I_{3}$ & $0.08{ }_{1} 3$ & 0.0854 & $302 \cdot 605$ & $33^{1} \cdot 24^{2}$ & $323 \cdot 286$ & $304 \cdot 54^{8}$ \\
\hline 7 & 0.0787 & 0.0819 & 0.08 I 3 & 0.0854 & $304 \cdot 899$ & $33^{I} \cdot 487$ & $3^{26} \cdot 8$ I 3 & 304.97 I \\
\hline 8 & 0.0793 & 0.0819 & 0.0819 & 0.0869 & 319.047 & $33^{2} \cdot 183$ & $350 \cdot 325$ & $311 \cdot 568$ \\
\hline 9 & 0.08 I 3 & 0.0826 & 0.0819 & 0.0884 & $33^{\circ} \cdot 13^{2}$ & $347 \cdot 508$ & $356 \cdot 207$ & $321 \cdot 797$ \\
\hline IO & 0.0854 & 0.0833 & 0.0826 & 0.0909 & $33^{2} \cdot 282$ & $34^{8} \cdot 097$ & $359^{\circ} 5^{25}$ & $33^{8} \cdot 93^{8}$ \\
\hline Means & 0.07886 & 0.08035 & 0.08064 & $0.0843^{6}$ & $303 \cdot 68 \mathrm{I}$ & $328 \cdot 6_{5}$ I & $3^{27} \cdot 3$ I 8 & $300 \cdot 04^{8}$ \\
\hline
\end{tabular}

$$
\begin{gathered}
\text { D.F. }: 3 ; 36 . F=5 \cdot 147 . \quad \text { D.F. }: 3 ; 36 . F=5 \cdot 979 . \\
P<1 \text { per cent. }
\end{gathered}
$$

the chromosome IV was not controlled, and that some rare crossovers can also occur, when crossover preventing inversions are present. For that reason, we must be cautious in considering the variation shown by the females as being pure non-heritable. Meanwhile it cannot be denied that males and females show a degree of homogeneity which is substantially different.

(c) $\mathrm{m}^{+}$and $\mathrm{m}^{2}$, as oligogenes acting on cell size.-The existence of the major gene miniature ( $\mathrm{m}^{2}$, Dobzhansky, I 929) acting on the cell size, permits us to analyse the relationships between this and the systems of polygenes previously considered.

The stock carrying $m^{2}$ was actually marked by the genotype: $m^{2} g$. Crosses were made with the usual stocks in order to obtain 
males carrying the different $Y^{\prime}$ 's and $m^{2}(I ; 36 \cdot I)$. These males are heterozygotes, having one-half of the chromosomes from the $\mathrm{m}^{2} \mathrm{~g}$ stock and one-half from Oregon, except the Y chromosome, which is, respectively : Oregon, Luino, Oerlikon or Crkwenika.

The measurements made on the original $\mathrm{m}^{2} \mathrm{~g}$ stock and on homozygous Oregon are given for comparison in table 4. It is clear that

TABLE 4

Comparison between males with $\mathrm{m}^{+}$(Oregon) and with $\mathrm{m}^{2}$

( 40 individuals for the wing cells, and Io for the cornea)

\begin{tabular}{|c|c|c|c|}
\hline & & Wing cells & Cornex \\
\hline $\begin{array}{l}\text { Oregon }\left(m^{+} Y\right) \\
\text { Miniature }^{2} Y\end{array}$ & $\begin{array}{l}. \quad . \\
. \quad\end{array}$ & $\begin{array}{l}0.080640 \pm 0 \cdot 0006 \text { I } 08 \\
0.037566 \pm 0.0008432\end{array}$ & $\begin{array}{l}327 \cdot 318 \pm 6 \cdot 582 \\
268 \cdot 261 \pm 5 \cdot 912\end{array}$ \\
\hline Difference & . & 0.043074 & $59 \cdot 057$ \\
\hline
\end{tabular}

the conclusions by Dobzhansky (1929) concerning the wing cells are confirmed, and further the results show that the gene also affects the eye cornex.

The data for the heterozygous $\mathrm{Y} / \mathrm{m}^{2} \mathrm{~g}$ males are given in table 5 and show that a significant difference exists between stocks for the

TABLE 5

Males with $\mathrm{m}^{2}$. Each figure corresponds to the mean taken from Io individuals for the wing cells, and from 3 individuals for the cornee

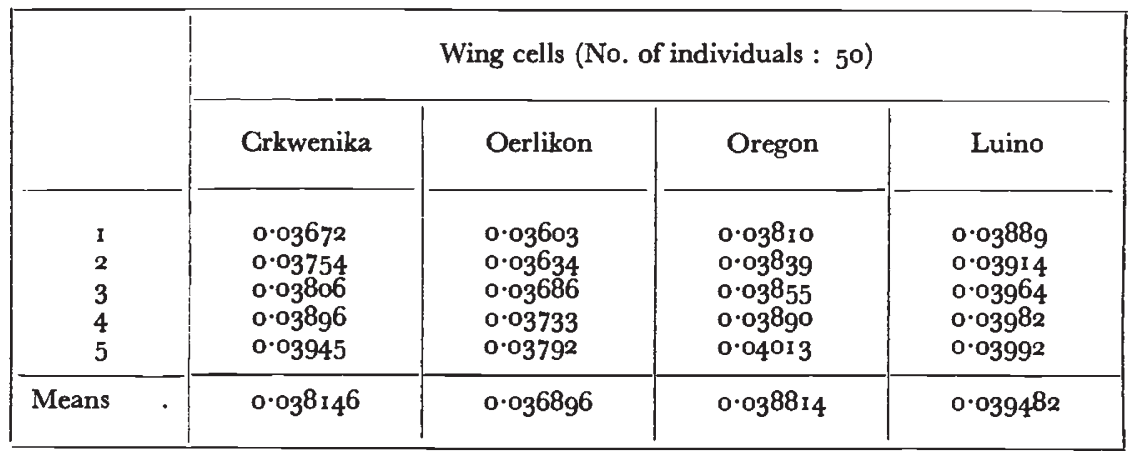

D.F. : $3 ;$ I6. $F=9.444 . \quad P<1$ per cent.

\begin{tabular}{|c|c|c|c|c|}
\hline & \multicolumn{4}{|c|}{ Cornex (No. of individuals : 15 ) } \\
\hline $\begin{array}{l}1 \\
2 \\
3 \\
4 \\
5\end{array}$ & $\begin{array}{l}279 \cdot 738 \\
282 \cdot 553 \\
306 \cdot 763 \\
306 \cdot 979 \\
329 \cdot 559\end{array}$ & $\begin{array}{l}282 \cdot 436 \\
291 \cdot 768 \\
301 \cdot 501 \\
304 \cdot 734 \\
315 \cdot 730\end{array}$ & $\begin{array}{l}277 \cdot 645 \\
278 \cdot 470 \\
297 \cdot 555 \\
303 \cdot 681 \\
316 \cdot 574\end{array}$ & $\begin{array}{l}274 \cdot 883 \\
283 \cdot 470 \\
284 \cdot 557 \\
285 \cdot 577 \\
294 \cdot 171\end{array}$ \\
\hline Means & $301 \cdot 118$ & $299 \cdot 233$ & $294 \cdot 785$ & $284 \cdot 53 I$ \\
\hline
\end{tabular}

D.F. $=3 ; 16 . \quad F=1 \cdot 211 . \quad P>5$ per cent. 
wing cells, but not for the corneæ. The conclusion is thus justified, that, when $\mathrm{m}^{2}$ is present instead of the allele $\mathrm{m}^{+}$, the polygenes of the $\mathrm{Y}$ chromosome modify the expression of the main gene as far as the wing cells are concerned, but not its effect on the corneæ.

Obviously, the data were obtained after a preliminary investigation to test the homogeneity within each stock. Beside the males, a corresponding number of females was also examined, to test whether the presence of $\mathrm{m}^{2}$ in heterozygous condition is able to influence the phenotype. We conclude from this investigation that it is not strong.

It may be quoted, incidentally, that a semidominance of $m^{2}$ is found, since the values for mean wing cells and corneæ for Oregon females are respectively: $0.6695 ; \mu^{2} 35^{1} \cdot 354$ and for miniature ${ }^{2}$ females : wing cells, o.4II 5 ; corneæ $\mu^{2} 29 \mathrm{I} \cdot 687$.

\section{DISCUSSION}

The data, which we are now going to discuss can be summarised as follows :--

(i) The stocks change over a series of generations (even when kept in the most constant culture conditions and with severe inbreeding) with respect of wing and cornea cell size in both sexes, and thus probably independently from the $\mathrm{Y}$ chromosome effect.

(ii) The $\mathrm{Y}$ chromosome, in agreement also with the previous investigation of the senior author, exerts an influence on the cell size of the male.

(iii) The pair of alleles $m^{+}-m^{2}(I ; 36 \cdot I)$ also acts on the cell size of both wings and corneæ, but more strongly than the $\mathrm{Y}$ chromosome and the other polygenes. The allele $m^{2}$ interferes in a peculiar way with the action of the $\mathrm{Y}$ chromosome, being effective on wing cells and not on corneæ.

Certain problems can now be separately discussed.

(a) Activity of the $Y$ chromosome as a system of polygenes.-In a previous paper by the senior author (195I) some evidence was given supporting the view that in the $\mathrm{Y}$ chromosome a system of polygenes is at work. Actually, on the basis of one single factor, it would be difficult to explain the quantitative differences among stocks. The present work shows better evidence of the polygenic content of this chromosome; namely, the changes observed in the Y's after a number of generations (table I). It is clear that such changes can be better understood on a polygenic basis, owing to the mechanisms of genotypic variation, which can be accounted for primarily by mutation and crossing-over. The first phenomenon is rare for one single locus, but, after a relatively 
short number of generations, may occur rather frequently if the number of genes involved is high. The variation by means of crossing over is also obviously understandable for the pairing segment between $\mathrm{X}$ and $\mathrm{Y}$, assuming the presence of many genes located in the same chromosome, and acting in a similar manner.

These polygenes are considered to form a system in the sense that they work together on the cell size. The activity of such a system is not independent but modifies the effect of other factors. Among these, some can be considered as main genes according to Mather (1949), and up to now two of these have been determined. In the previous paper, a modification was described which is determined by the $\mathrm{Y}$ chromosome on the frequency of irregular eye facets, produced by the SB Me' inversion (chromosome III ; Di Pasquale, I 95I). In the present paper, a similar modification was shown for the pair of alleles $m^{2}-m^{+}$, and thus acts in a very peculiar way. The allele $m^{+}$ (greater cells) is modified in its expression by the $\mathrm{Y}$ chromosome, while $m^{2}$ (smaller cells) can be modified only in its effect on wing cell size. It must be noted that it cannot be excluded that other factors work with $m^{2}$, since the stock carrying $m^{2}$ was not made homogeneous with the other stocks.

The genotypic variation of cell size must also depend on another element, i.e. the sex determining factors. Little is known about the localisation of these factors, but it is nonetheless certain that they act on cell size (and probably also on cell number), determining a difference in size between male and female. In the present work both cell measurements show a greater size in the females, but the data collected in table I show clearly that the difference in cell size between sexes can be modified to such extent by the $\mathrm{Y}$ chromosome, as to become negligible (e.g. the Luino stock at the ist oregonisation).

The Y chromosome genes of Drosophila melanogaster, except for the few major genes located in it, must therefore be considered to act as a system of modifiers. The modification seems to control several characters beside the cell size, for example "mottling effect", "Podoptera effect" (Goldschmidt et al., I95I). This action leads to an understanding of the importance of the $\mathrm{Y}$ chromosome, for its possibility of adjusting the expression of oligogenic characters can be useful in selection, when several types of $\mathrm{Y}$ chromosomes are present in a population.

We do not dare, on the other hand, to extend the conclusions reached for $D$. melanogaster to other species, until appropriate data are collected.

One last point to be considered, concerns the action of polygenes located in the $\mathrm{Y}$ chromosome.

The question shows two main sides : that of the pleiotropism, and that of the actual mode of action on the cell size.

How to understand pleiotropism in the character studied has been discussed previously (Barigozzi, I95I) and we still incline to 
consider the present case (i.e. action on cell size) as a spurious example. The reason is that an effect on all cells affect automatically all organs by means of one single mechanism, and not by means of different modes of action, as it occurs in the true pleiotropism.

The action of the different genes on cell size can be understood in different ways.

The genes located in the $\mathrm{Y}$ chromosome can support the view put forward by Caspersson (1950), and already discussed previously (Barigozzi, I 95 I), i.e. of a participation in the protein synthesis during the growth processes. The action played by the pair $m^{+}-m^{2}$ cannot be put in the same category.

(b) Polygenes and major genes.-An important question raised several times concerns the difference between polygenes and major genes or oligogenes.

The difference is maintained by Mather (1949), who attributes to the polygenes small, similar and supplementary effects, and to the major genes such great action that-except in polyploids-the homozygous deficiency of one locus of each cannot be compensated by another. Mather gives an analogy of his idea in which major genes might be compared to the skeleton of the genome, the polygenes being their cloth. The Author, on the other hand, believes that between polygenes and oligogenes should exist transitional stages. In addition, Mather considers that pleiotropy is so far not proved for polygenes, although he does not exclude the possibility (Mather, I 949, p. I 02).

Against this view, objections were raised by Robertson and Reeve (I952), pointing out that oligogenes have often a very slight effect, and that some alleles (iso-alleles) overlap. These remarks-we believe-seem based on a misunderstanding of Mather's thought, because the question does not concern the intensity of effect of alleles between them, nor the existence of small mutation steps. The point is that some genes (oligogenes) give rise to lethal genotypes in the case of their homozygous deficiency, while some genes (polygenes) do not, because other genes-duplicating their action-can replace those which are lacking. That such genes exist is actually proved by several sets of evidence. One is provided by the $\mathrm{Y}$ chromosome of $D$. melanogaster where only a few oligogenes are located, together with other multiple factors or polygenes, according to Mather and to the data shown in the present paper. These factors-as many investigations have shown for the $\mathrm{Y}$ chromosome-are unable to cause lethality when deficiencies occur.

The present paper, thus, supports the view that oligogenes and polygenes collaborate to determine a character (the cell size). The difference between two types of genes (which must obviously be considered connected by intermediate types) appears in the case in question by no means as qualitative, but purely as a quantitative one, the oligogene $m-m^{+}$alone being capable of producing a considerable effect, which numerous polygenes cannot equal. 
One point in the polygene theory is considered by Mather, but largely elaborated by Robertson and Reeve (1952) and even more generally by Grüneberg (1952); that oligenes might have secondary effects, detectable as polygenic. This remark, tending obviously to eliminate any difference between oligogenes and polygenes cannot be ignored. It is possible that in some cases it may be true. Nonetheless, the $\mathrm{Y}$ chromosome of $D$. melanogaster provides an example of a system of genes, where a prominent polygenic activity exists.

(c) Sources of genotypic variation in cell size.-The foregoing discussion leads to a consideration of cell size as changing under genic control.

In order to see as clearly as possible the changes occurring in the case involved, we must consider a population of flies, where mutation and crossing-over act constantly. Owing to the rarity of mutation for single loci, changes in cell size, as big as those brought about by a mutation step of oligenes, like from $m^{+}$to $m^{2}$ or vice versa, will contribute but little (or after long selection processes of casual fixation of genes) to the genotypic variation of the population. On the other hand, the mutability of a high number of polygenes scattered throughout the genome, including the $\mathrm{Y}$ chromosome, can provide a rather large number of new genotypes, producing very small, but. relatively frequent changes in cell size.

The question now arises of the selective significance of the cell size. The cell size, actually, must be considered as correlated with the organ size, where the relationship between cell and organ size is mainly represented by the number of cells. When this number remains constant, every variation in cell size results in a parallel variation in the organ size. When the cell number decreases on the other hand, the cell size increase can also be counteracted, and the organ can even diminish as a whole. One secondary factor in determining the organ size is represented by the intercellular substances, which in certain tissues can play an important role; this is not the case for the wing.

For the wing of $D$. melanogaster we know after the investigations by Robertson and Reeve (1952), that not only the wing surface, but also the thorax length depends on cell size. We can thus imagine, how the continuous variation of cell size produced by polygenic action, can be intensively modified by selection.

Apart from the case of $D$. melanogaster, it will be worth investigating other species where big $\mathrm{Y}$ chromosomes are present (as in some Rodentia), whether a similar complex determination of cell size is at work.

\section{SUMMARY}

I. Cell size was analysed both on the wing and on the cornex of $D$. melanogaster, with the aim of studying its genetic determination.

2. Three groups of genes have been found acting on this character : (i) the pair of allelomorphs $\left(m^{+}-m^{2}\right)$ located at $36 \cdot \mathrm{I}, \mathrm{I}$. 
(ii) many other genes located throughout the genome, which have not been analysed in detail.

(iii) many genes acting as polygenes, located in the $\mathrm{Y}$ chromosome.

3. The alleles $m^{+}-m^{2}$ act as major genes, and in some of their manifestations are modified by the $\mathrm{Y}$ chromosome.

\section{REFERENCES}

BARIGOzZI, C. I 95I. The influence of the $Y$ chromosome on quantitative characters of D. melanogaster. Heredity, 5, 41 5-432.

BRIDGes, B. G., AND BREME, K. s. 1944. The mutants of D. melanogaster Carn. Inst. Washington Publ. 552.

Caspersson, T. 1950. Cell Growth and Cell Function. New York : Norton.

Di Pasquale, A. 1950. La manifestazione nell'occhio connessa con In (3R) Mé

di D. Melanogaster. Rend. Ist. Lombardo. Sci. Let., Cl. Sci., 83, 425-443.

DOBZHANSKY, T. I929. The influence of the quantity and quality of chromosome material on the size of the cells in D. melanogaster. Arch. f. Entw., ${ }_{115}, 363,379$.

Goldschmidt, R. B., hanNah, A., AND Piternick, L. K. 195I. The Podoptera effect in D. melanogaster. Univ. Calif. Publ. Zool., 55, 67-294.

GRÜNEBERG, H. 1952. Genetical studies on the skeleton of the mouse IV. $\mathcal{J}$. Genet., 5I, 95-1 14 .

MATHER, K. 1944. The genetical activity of heterochromatin. P.R.S., B, 132, 308-332.

MATHER, K. 1949. Biometrical Genetics. London : Methuen.

ROBERTSON, F. W., AND REEVE, E. I952. Studies in quantitative inheritance I. 7. Genet., 50, 414-448.

Waddington, c. H. I 943 . Polygenes and oligogenes. Nature, Lond., 15I, 349. 